\title{
A New Consensus on Monetary Policy?
}

\author{
Um novo consenso sobre a política monetária?
}

EDWIN LE HERON****

RESUMO: Ao analisar os documentos emitidos pelo Banco do Canadá, uma política monetária original pode ser vista. A política monetária canadense tenta manter sua autonomia e, ao mesmo tempo, respeitar as taxas de câmbio flutuantes. As numerosas inovações são a base de um novo consenso sobre política monetária. Longe da regra do dilema versus discrição dos antigos métodos monetaristas e keynesianos, um novo dilema será o foco: o da credibilidade versus confiança. Aqui, as antecipações dos agentes econômicos, o comportamento dos mercados financeiros e o preço dos ativos desempenham um papel dominante. Com base no experimento inovador do Banco do Canadá durante a década de 1990, as características do Novo Consenso serão explicadas. Longe de tornar bancos centrais independentes algumas instituições de alta potência, isso os mostra como "estátuas com pés de barro".

PALAVRAS-CHAVE: Banco Central; política monetária; metas de inflação; Banco do Canadá; credibilidade versus confiança.

ABSTRACT: By analyzing the documents issued by the Bank of Canada, an original monetary policy can be seen. The Canadian monetary policy tries to maintain its autonomy, whilst at the same time respecting floating exchange rates. The numerous innovations are the foundation of a New Consensus on monetary policy. Far from the dilemma rule versus discretion of the former Monetarist and Keynesian methods, a new dilemma will be the focus: that of credibility versus confidence. Here, the anticipations of the economic agents, the behavior of financial markets and the price of assets play a dominating role. Based on the innovative experiment of the Bank of Canada during the 1990s, the characteristics of the New Consensus will be explained. Far from making independent central banks some high-powered institutions, it shows them instead to be "statues with feet of clay".

KEYWORDS: Central banking; monetary policy; inflation targeting; Bank of Canada; credibility versus confidence.

JEL Classification: E50; E52; E58; N42.

* Centre de Recherches et d'Études sur le Canada et le Québec en Sciences Sociales (CRECQSS), Institut d'Études Politiques, Bordeaux, France. E-mail: e.le.heron@sciencespobordeaux.fr.

** President of the French Association for the Development of Keynesian Studies (ADEK). 
Since the beginning of the 1990s, monetary policy has widely changed. Historical, institutional and theoretical reasons have justified these evolutions. More limited for countries that dominated a particular area of currency (USA, Germany, Japan), these changes were much deeper for "dominated" countries such as Brazil, Canada or France. While the new theoretical approaches (New Classical and New Keynesian schools) are well known, the evolution of the institutional frame is much less understood.

With the end of fixed exchange rates system, born of Bretton Woods, and with increasing inflation, monetary problems were to the fore after 1973. Monetary policy became self-governing with the adoption of monetarist regulation in place of the Keynesian framework. There was then only one internal objective: the control of inflation. However floating exchange rates stabilized neither the exchange rates nor the balance of payments. External constraints of monetary policy had always existed. The globalization of trade led to the development of more or less Optimal Currency Areas according to Mundell's definition. However, an opposition appears between the "dominating" countries on a currency area, which can choose the internal objectives for the monetary policy, and the "dominated" countries that are often forced to seek the external objective. The strongest regional economic integration, with Nafta for North and Central America and the European Monetary Union for twelve European countries, made the choice of the exchange system more difficult. The autonomy of national monetary policies was questioned (Mundell's triangle of incompatibility). At the end of the 1980s, the instability of monetary aggregates, the rising importance of financial markets with recurring crises, accompanied with a self-confidence liberal ideology, led to the gradual adoption of a "new consensus" on monetary policy. At the beginning of 1990 s, numerous countries adopted a unique objective of inflation-control target and abandoned other intermediate targets (such as the monetary aggregates). New Zealand was the first country to do this in 1989, followed by Canada in 1991 then by United Kingdom in 1992, by Finland and Sweden in 1993, Australia and Spain in 1994.

An attempt to clarify the following questions will be made:

What are the differences between the "New Consensus" and the Keynesian or Monetarist system that preceded it? As we are familiar with frequent monetary and financial crises, is it possible to guarantee monetary stability? What part do financial markets play in the determination of today's monetary policy?

It is the Canadian experiment of the last ten years that will be analyzed. Indeed, this country was a precursor for this new consensus during the 1990s and its close relationship with the area of the dollar is particularly interesting to study. The conventions of the central bank of Canada (BofC) (response function, backgrounders and publications) will be examined in order to understand its behavior. The objective is not to judge the efficiency of this monetary policy, but to clarify its definition, its foundations and its innovations. Firstly, there will be an examination of the central bank of Canada and its monetary policy. Secondly, an attempt will be made to define the New Consensus by comparing it to those that preceded it. 


\section{CANADA IN THE 1990S: AN ATTEMPT \\ OF AUTONOMY FOR THE MONETARY POLICY}

In the 1990s, Canada and France were monetarily "dominated" countries in their regional area. But, contrary to France which chose fixed exchange rates and the renunciation of autonomy of its monetary policy to allow the construction of the single currency in Europe - Canada preferred floating exchange rates to maintain a relative autonomy of its monetary policy. This obliged its central bank to innovate from 1991.

\section{Target, strategy, instrument and transmission of monetary policy}

With a very open economy ( $80 \%$ of its foreign trade being with the USA) Canada chose floating exchange rates to preserve autonomy of its monetary policy. As Mundell showed, in a globalized economy where the capital freely circulates, it is impossible to pursue an external objective of exchange rate and the internal objectives of inflation and growth simultaneously. As today the only available instrument for central banks is the interest rate, the triangle of incompatibility is strengthened. The important difference of the production structure between Canada and the United States justifies floating exchange rates. This difference explains and requires separated evolutions for each currency. According to BofC, the definition of monetary policy follows seven stages:

(1) In February 1991, Canada was one of the first countries ${ }^{1}$ which adopted an inflation-control target. The target range currently extends from 1\% to 3\% (established for 5 years 2001-2006). The secondary objective is to minimize the output gap, measured by the difference between the economy's actual output and the level of production it can achieve with existing labor, capital, and technology without putting sustained upward pressure on inflation. Inflation-control target is about the expected inflation and it aims to influence the anticipations of economic agents.

"At our fixed announcement dates, we are not trying to affect today's inflation. What we are aiming at is future inflation and acting pre-emptively to achieve a balance in supply and demand going forward.” (Dodge, 2002)

Inflation-control target is defined by the central bank. Understandably, it allows directly the efficiency of the monetary policy to be measured. The price index to be respected is the global Consumer Price Index (CPI). To assess the trend of inflation, the BofC finds it very helpful to use the "core CPI", which excludes the eight most volatile components (fruit, vegetables, gasoline, fuel oil, natural gas, mortgage interest, intercity transportation, and tobacco products) as well as the effect of changes in indirect taxes on the remaining components.

\footnotetext{
${ }^{1}$ In 1991, the target midpoint fixed by the Bank of Canada was 3\% for the end of 92 , then $2 \%$ (target range from $1 \%$ to $3 \%$ ) for the end of 95 , renewed twice for three years, before being fixed for five years (2001-2006).
} 
(2) The central bank anticipates the actual output and the potential output tomeasure the expected output gap. The output gap is then referred to as spare capacity or excess capacity. To determine the level of potential output, the function combines with the concept of Nairu and so accepts the Monetarist conception. However, both the level of potential output and the output gap are estimated numbers and, therefore, there is a major uncertainty in their calculation. As a result, the BofC now weights more heavily a range of indicators in order to assess the degree of pressure on the economy's production capacity (movements in inflation relative to expectations, the growth of money and credit, wage pressures, and evidence of supply bottlenecks). The central bank claims to be equally concerned with both the negative and the positive output gaps.

(3) The BofC calculates for the Monetary Conditions, i.e. the combined effect of the level of short-term interest rates and the exchange rate for the Canadian dollar, a path of the inflation over two years. To keep inflation within the range $(1-3 \%)$, monetary policy needs to aim at the $2 \%$ target midpoint over the six to eight quarters that are required for monetary policy to have most of its effect. The Monetary Conditions Index ${ }^{2}(\mathrm{MCI})$ is at the center of the device and of the response-function of the central bank (Diagram 1$)^{3}$.

Diagram 1: Monetary Conditions Index (in January 87, the $\mathrm{MCl}=0$ )

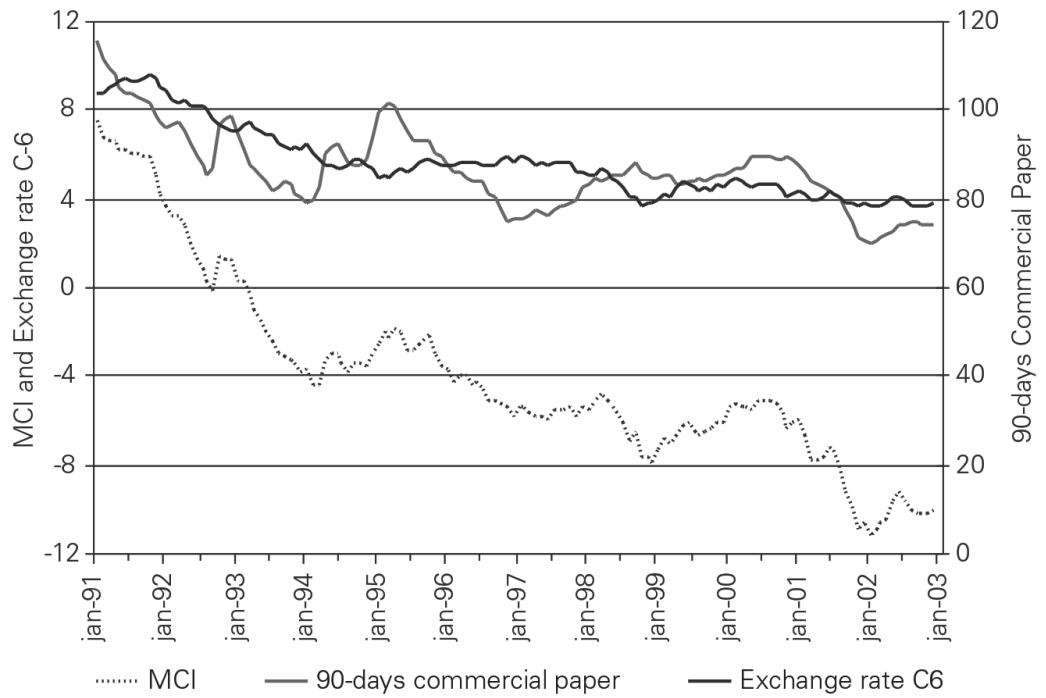

\footnotetext{
${ }^{2}$ However, it is necessary to say that with the replacement of Gordon Thiessen by David Dodge in 2001, the importance given to the $\mathrm{MCI}$ is lesser, though it seems to us that its use is unquestioned. Gordon Thiessen was the governor of the Bank of Canada from 1994 till 2001. Prior to him, it was John Crow (1987-1994).

${ }^{3}$ The author built all the diagrams from the data available on the BofC web site, managed by Eades, webmaster@bank-banque-canada.ca.
} 
The MCI is meant to provide a measure of the degree of ease or tightness in monetary conditions relative to a base period. The MCI captures the effect monetary policy has on the economy both through interest rates and the exchange rate. Following empirical calculations, the interest rate receives a weight of 1 , and the exchange rate receives a weight of $1 / 3$. These represent the relative effect that changes in short-term interest rates and the exchange rate have on output.

The MCI formula is:

$$
\mathrm{MCI}=(\mathrm{CP} 90-7.9)+(100 / 3) \times(\ln (\mathrm{C} 6)-\ln (91.33))
$$

With: CP90 = Canadian 90-day Commercial Paper rate; C6 = Canadian dollar index. It is an index of the trade-weighted exchange value of the Canadian dollar against six major foreign currencies (US\$, Euro, Yen, $£$, Swiss franc, Swedish krona) $(1992=100)^{4}$. The weights are calculated using the trade flows between Canada and the countries in the index, to measure the relative importance of their effects on the global demand.

The MCI is conventionally calculated to be equal to 0 in January 1987 . Evidently, the compounding of the monetary conditions is not mastered by the central bank and some combinations are preferable to others. It's better to have low interest rates and a high exchange rate than the inverse.

This allows to the central bank of Canada to have an autonomous monetary policy thanks to floating exchange rates, whilst integrating the exchange rate channel of transmission. This is important for such an open country because the USD value strongly influences the demand of goods and services.

(4) The bank of Canada determines the Target for the Overnight Rate ${ }^{5} i_{j}$ (the BofC's official rate or key policy rate). The monetary policy is implemented in a regime with zero reserve requirements ${ }^{6}$. The reserve requirements are replaced by financial penalties when the amount of the bank reserves moves away from zero.

In a floating exchange system, the policy transmission is made by the medium and long-term interest rates channel $\left(\mathrm{i}_{\mathrm{MT}}, \mathrm{i}_{\mathrm{LT}}\right)$ and by the exchange rate channel $e$

\footnotetext{
${ }^{4}$ C6 $6=100 *\left(1\left(\left(\right.\right.\right.$ USA $\left.^{* * 0.8584}\right) \mathrm{x}\left(\mathrm{Japan}^{* * 0.0527)}\right) \mathrm{x}\left(\mathrm{UK}^{* * 0} 0.0217\right) \mathrm{x}($ Sweden $* 0.0035) \mathrm{x}($ Switzerland $* *$ $0.0043) \mathrm{x}\left(\mathrm{EMU}^{* * 0.0594))}\right) / 1.046294 * *$ means exponent.
}

${ }^{5}$ The Target for the Overnight Rate is the midpoint of the Bank's operating band for overnight financing. The official rate was formerly the Bank Rate, which is the upper limit of the operating band. "The Bank of Canada operates a system to make sure trading in the overnight market stays within its "operating band." This band, which is one-half of a percentage point wide, always has the Overnight Rate Target at its centre. For example, if the operating band is $4.25 \%$ to $4.75 \%$, the Overnight Rate Target would be $4.50 \%$. Since the institutions know that the Bank of Canada will always lend money at a rate equal to the top of the band, and pay interest on deposits at the bottom, it makes no sense for the institutions to trade overnight funds at rates outside the band. The Bank of Canada can also intervene in the overnight market at the Target rate, if the market rate is moving away from the Overnight Rate Target." (Bank of Canada, july 2001).

\footnotetext{
${ }^{6}$ On this subject, see (Kevin Clinton, 1998). Clinton and Howard examine the effect of eliminating reserve requirements on the linkages between the one-day interest rate, over which the Bank has the most influence, and other rates of interest.
} 
which are in the MCI formula. The more the increase of the short rate seems settled, the more it echoes in the long rates. The changes in long rates are a function of the evolution foreseen for the real rates, of risk premium and of the anticipated inflation rate. The changes in the exchange rate depend on the expectations of the market concerning the national policy and on external effects as the American policy, the evolution of the raw materials prices or the relative cyclical position. Interest rate changes can take from 18 to 24 months to work their way through the economy and to have a significant effect on inflation. A dynamic process of adjustment takes place in the economy in the following stages:

$\Delta \mathrm{i}_{\mathrm{j}} \Rightarrow \Delta \mathrm{i}_{\mathrm{MT}}, \mathrm{i}_{\mathrm{LT}}$ and $e \Rightarrow \Delta \mathrm{MCI} \Rightarrow \Delta$ Spending and Sales $\Rightarrow \Delta$ Production, Employment $\Rightarrow \Delta$ Price

Evidently the central bank does not try to react to the daily variations of the exchange rate. To determine the right moment for its intervention, the central bank should take into account the situation of financial markets. It should distrust extrapolative anticipations on the exchange market, hence the necessity of systematically explaining the situation and the monetary policy. The bank's actions should not be misinterpreted.

"Timely, measured steps are necessary to ensure that the economy can grow on a sustainable basis - that is, without generating inflation pressures. Because of the lag, monetary policy must focus on the future, rather than the present. By always acting in a forward-looking manner, the Bank of Canada aims to pre-empt future inflation and keep it within its inflation-control target range.” (BofC, 2001)

(5) It supposes that there are no supplementary shocks. So the trajectory corresponds to that wished for the given Monetary Conditions.

(6) The other scenarios, including "risk scenarios", are elaborated to see howthe Monetary Conditions would react.

"The idea is to re-examine the scenarios on which policy actions are based as new information becomes available. In this context, I would note that we are very aware of the uncertainty surrounding both the projection and the transmission mechanism that links our actions to demand and inflation." (Thiessen, 1998: 33)

(7) Rather, monetary conditions must be constantly re-evaluated and adjustedto respond to shocks of one sort or another ensuring that the economy remains on track to the inflation-control objective. If, as in 1994, the Bank estimates that the economy will be exceeding its capacity at some point in the future, the Bank may need to adjust monetary conditions ahead of time in order to prevent inflation pressures from building. Conversely, if the economy was expected to slow down, the Bank would take action to ease monetary conditions (by lowering interest rates) so that inflation would not fall below the target range. There are three kinds of shocks to analyze: 
(1) Those that cause variations in the desired level of the Monetary Conditions, but not in the actual level (for example a shock of demand).

(2) Those that cause variations in both the desired level and the actual level (asan increase of the raw materials prices makes the demand and the exchange rate rise).

(3) Those that cause variations in the actual level whilst not affecting the leveldesired by the BofC (exogenous shock of the exchange rate that the central bank should neutralize).

There is an iterative process from (2) to (7).

\section{Uncertainty, transparency and credibility: general philosophy of the Canadian monetary policy}

By referring to Nairu, the Canadian monetary policy remains inspired by Monetarism. Yet in practice, it is today radically removed from it. At the start of the 1980s, instability of the relationship between money supply and inflation led to the abandoning of a simplistic Quantitativism. As a BofC manager remarked at the time: "We did not abandon M1, it is M1 who abandoned us". So, the importance of a non-probabilistic uncertainty, the complexity of anticipations, the transparency, communication and credibility, and the games theory, have become the fundamental concepts of the new monetary policy.

The uncertainty is the major difficulty put forward by BofC managers for the definition and the transmission of the monetary policy. The optimism of Monetarism for inflation-control by the only central bank's money disappeared totally. As David Laidler asserts:

"The academic economist can very easily, and very often does, neglect such uncertainty, but the economist in a central bank does not have that luxury." (Laidler, 2001: p. iii)

Two kinds of uncertainty can be seen. The first kind includes unexpected events, external and internal shocks and errors in forecasting which can set the monetary policy off on a bad trajectory. The second kind arises when the private sector does not understand clearly the long-term objectives of the monetary policy. Gordon Thiessen warns that these two uncertainties can combine when markets do not know how to interpret the reaction of the monetary authorities to a shock. A different perception of the situation between central bank and markets creates problems and increases the uncertainty. When markets are "nervous and volatile", BofC prefers to stabilize them by choosing the exchange rate stabilization before returning towards the internal objectives (inflation and growth).

Central bank can take action concerning uncertainty. According to Thiessen (1995, 2001-2), central bank essentially experiences transparency, information and credibility. To reduce the uncertainty, G. Thiessen quotes six directions: 
(1) Keeping inflation low and stable is the best way to keeping the economyon the smoothest possible track for long lasting growth and job creation.

"I hasten to add that the goal of price stability is not at odds with the achievement of economic growth and expanding employment. Because price stability is helpful in making investment decisions that will improve productivity, it is good for growth.” (Thiessen, 1995: 13)

(2) An explicit inflation-control target should be announced, because it influences bit by bit the anticipations of economic agents.

(3) As Canada is in floating exchange rate, it is necessary to define an intermediate objective - such as the MCI - , which takes into account the exchange rate. Thiessen insists on the fact that to change the discount rate is not to change monetary policy, but is rather to adapt itself to current and anticipated Monetary Conditions. It increases the credibility of the action.

(4) To provide more transparency to its actions: there has been a target rangeof 50 basis points for the one-day rate. The Bank has intervened actively through its operations in the money market to hold the one-day rate within the range and to make the limits of the range clear to the market.

(5) It can reduce the uncertainty of the public and of the financial markets byclarifying the longer-term goal of monetary policy, the shorter-term operational targets at which it is aiming in taking policy actions, and its own interpretation of economic developments. The central bank should openly reveal all this information.

(6) Contrary to Monetarism, surprise in monetary policy should be banished. Thus, the high short-term volatility of the discount rate - essential in the monetarist method - would also disappear. To stabilize the anticipations, bank rates are maintained at the required level for as long as possible. The curve of evolution of the discount rate takes a characteristic shape of a stair. The Canadian policy shows this shape after1996 — long after the United States (Diagram 2).

Diagram 2: Discount rates of the Fed and of the Bank of Canada (Brent Eades, webmaster@bank-ba)

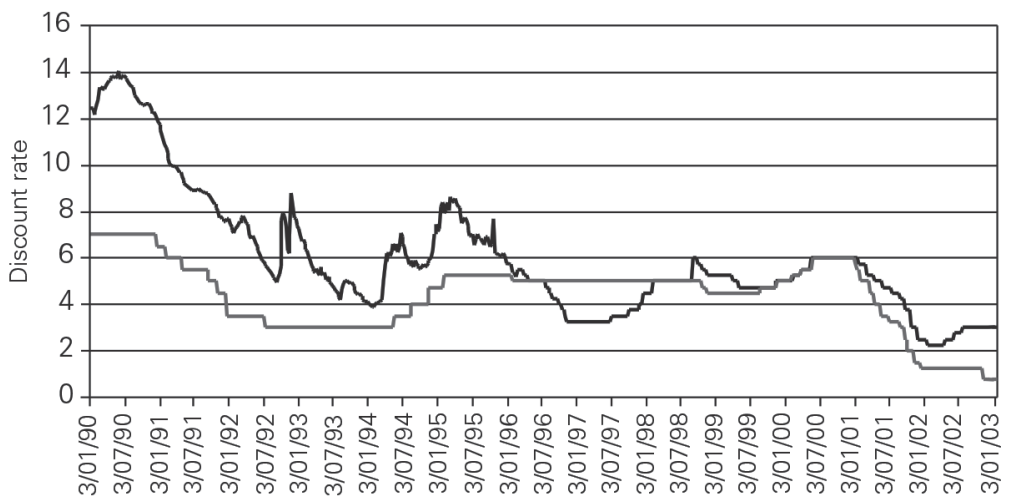

- BofC rate - FED discount rate 
It is necessary to use as much as possible the conventions of the market, on one hand by conditioning its expectations, on the other hand by trying to respect them. Credibility gives some certainty to react to shocks. Indeed a high transparency allows making the monetary policy transmission easier:

"As monetary policy has become more transparent, it has become evident that it works more effectively when financial markets and the public understand what the Bank is doing and why. We no longer regard surprise as an important element in monetary policy actions. We prefer to see private agents anticipate, rather than respond to, monetary policy actions." (Thiessen, 2000-2: 79)

On the other hand, the aggregates of money and credits are not very important any more.

"We use them primarily as indicators of future developments, rather than as links in the long causal chain from Bank of Canada actions to the rate of inflation." (Thiessen, 1995: 11)

These are only indicators. For a long time, the credit was seen as determined by the financing demand and financial institutions were passively content to satisfy it. With Monetarism, the monetary authorities believed in a vertical curve of money supply. The control of the central bank's money was enough to control credit. Today, the Bank of Canada asserts to propound itself two questions. Firstly, does monetary policy implementation involve an automatic adjustment of credit? That is, does an increase of the short-term interest rate inevitably imply a fall in credit demand (as with the IS-LM model)? If the answer is no, the central bank should keep a sharp eye on credit. Secondly, are there shocks that have their source directly on the credit market (as a "credit crunch")? But for the Bank of Canada, this approach by the credit channel hardly explains the global demand.

Obviously this increased power obtained by independent central banks highlights the problem of their responsibility before the nation and that of their relationship with the democratically elected government.

"I would argue that transparency and accountability give autonomous central banks legitimacy in a democratic society." (Thiessen, 1998: 39)

The inflation targets have made these performance assessments more straightforward. Article 14 of BofC Act represents not only the announced objective but also an accountability arrangement. This arrangement defines the nature of the Bank's relationship to the Minister of Finance in the area of monetary policy.

"The second part of the accountability arrangement for the Bank of Canada is the directive power given to the Minister of Finance under Section 14 of the Bank of Canada Act. With the new practice of agreed 
targets between the Bank and the Minister, the directive power, which has never been used, now seems even less likely to be used. Nonetheless, if there were a fundamental disagreement on the targets when they came up for renewal, the Minister could impose his will via a directive. That would likely lead to the Governor's resignation and a new Governor, who was prepared to accept the desired targets, would have to be chosen.” (Thiessen, 1998: 32)

Quite evidently, this is a power to be used only in extreme circumstances. Since the joint statements of BofC and the government show the degree of collaboration and agreement existing between both authorities, this offers reassurance on the bank's commitments.

The Bank of Canada holds three conclusions from its experiment in the 1990s. Firstly, regarding the uncertainty, monetary policy can not be led in a mechanical way. An automatic approach as Taylor's rule is not applicable. One needs a stable, medium-term target (inflation-control target, $\mathrm{MCI}$ ), that excludes the attempts at fine-tuning used to try and avoid the cyclic fluctuations.

Secondly, both the importance of anticipations on financial markets and the globalization of savings explain a high volatility of the rates. It is impossible to control all the range of rates. The main central bank's influence on the long-term rates proceeds according to the expectations of the market concerning inflation.

Thirdly, the more uncertain, globalize and opened markets make a greater transparency of the objectives necessary, especially for the implementation of the monetary policy. The ultimate objective, the action and reason for this action should be systematically clarified. However, the information is useful only if it is credible, hence the importance of respecting the commitments.

The Canadian results concerning the inflation were very good, even better than the United States at the end of decade. If the interest rate remained high, notably in 1994-1995, its evolution was better afterwards (Diagram 3). On the other hand, the growth and the unemployment remained very unsatisfactory, sanctioned by a regular decline of the exchange rate (Diagram 4). But this depreciation also exists for European (Euro) and South American (Real) currencies. A more financial explanation should be put forward. The prospects of the New Economy attracted "hot money" to the United States as well as the sense of a "flight to quality". This and the fact that it was the world reference currency were the determining elements for the $\$$ increase, in spite of a widely unfavourable balance of trade (1,5 billion of $\$$ are necessary a day).

If the autonomy of the BofC monetary policy, notably towards the United States, is evident during period 1991-2002, the adoption of the MCI could give the impression of a policy that alternates between fighting against the inflation in pure floating exchange rate system (internal objective) and defending the currency in flexible exchange rate system (external objective). There may also be reason to wonder about the autonomy of the monetary policy towards financial markets which require strong 
currency and weak inflation. An attempted judgment will not be made concerning a possible deflationary effect of the BofC policy, leading to interest in

Diagram 3: Differential of discount rates (Bank of Canada-FED)

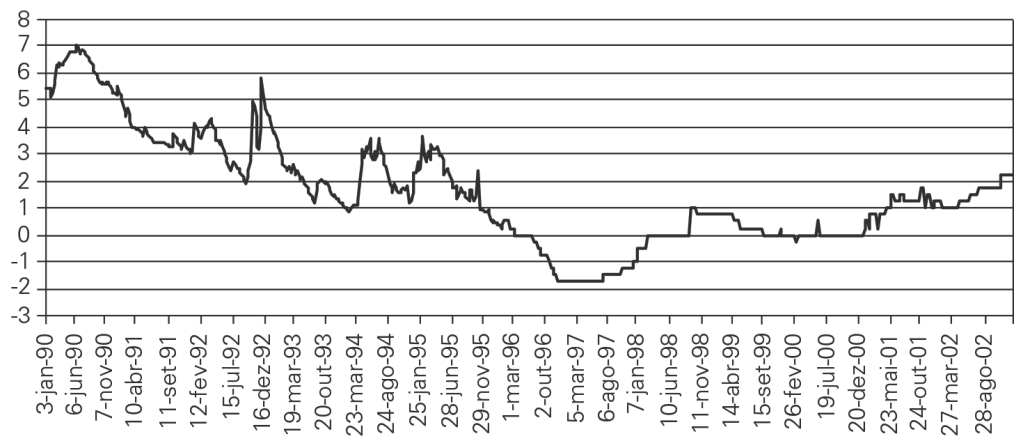

the central banks conventions and so in the development of a new monetary consensus. The Bank of Canada's speech and its numerous innovations suggest a new strategy in monetary policy, which will here be characterized.

Diagram 4: Exchange rate \$ and Real (Brazil)/ Canadian \$

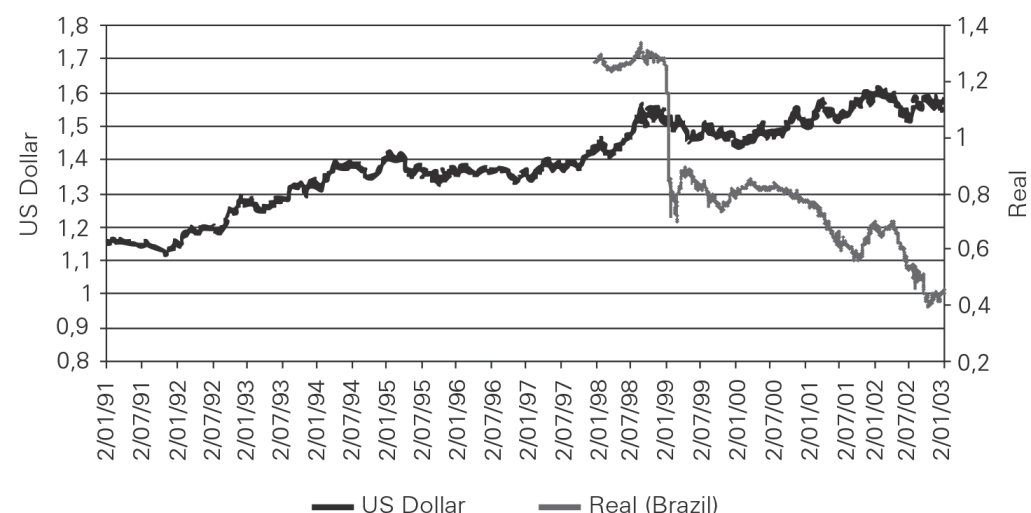

\section{MONETARY POLICY: A NEW CONSENSUS?}

After WWII, the main social democrat project was in favour of a liberal policy in which man, and so statesman, was at the heart of the building of institutions. If this policy criticizes the socialist utopia, it assumes that "Reason" is necessary for the progress of democracies. At the start of the 1970s, which mark the end of the Keynesian consensus, a radicalization of liberal policy started; first via Milton Friedman and the Chicago School, and then via the return of "New" Classical theses and Friedrich Hayek. The collapse of the socialist alternative also reinforced this process of radicalization. However, one notes that the new model of monetary policy has kept a liberal position that is mildly similar to Friedman's and has re- 
jected those of the ultra liberals and Hayek. Ultimately, New Keynesians rather than New Classicals have influenced the views and behaviour of modern central banks.

Thus, since the early 1960s, three systems ${ }^{7}$ of monetary policy have existed in succession: Keynesians until 1973-74; Monetarist until of the end of the 1980s; and finally a "New Consensus" since the 1990s. After a brief review of the first two systems, a clearer definition will be given of this new consensus by relying mainly on Canada, which was one of the first countries to apply this system.

\section{A short historical review of the systems of monetary policy since 1960}

\section{1) The Keynesian model}

During the 1960s, the Keynesian model ${ }^{8}$ is applied approximately everywhere. The social democrat liberalism, politics, statesmen and so "Reason", are at the centre of the economic views. The naturalist or "spontaneous" view of liberalism is rejected. In 1969, Raymond Aron represents this position:

"An economic system is always a human creation: in this respect, market mechanisms are not different from planned centralization. If formerly, the market was judged to conform to nature and to be the result of natural laws, these views are only incidental to the history of ideas. The scientific content of the education of economists is usually enveloped and concealed behind ideological representations, value judgments, and metaphysics that characterize a period and are inevitably condemned to ineluctable outdating. Thus liberalism has often been distorted into natural law whereas, in reality, it needs political art — and the highest art -, to develop.”

For Keynesian, the statesman is the only one who can think globally and so deal with macroeconomic problems. He is the only one that can make global anticipations and imagine an optimal situation. Yet, because of anticipations of economic agents - particularly those of entrepreneurs that do not lead spontaneously to social optimal market equilibrium - the statesman must intervene in the market.

\footnotetext{
${ }^{7}$ One defines a system of monetary policy by a coherent strategy of actions based on an institutional system and a theoretical corpus. The problematic of this system depends on the historical evolution of the economic system of each country. However, this evolution is both endogenous and exogenous. The rise of liberalism largely justified and imposed the changes of the 1980s (disintermediation, deregulation, opening up of financial and banking system).

${ }^{8}$ One can find it in the Porter Report for Canada, which is the equivalent of the Radcliffe Report for the UK. The Porter Commission worked from October 1961 to 1964. By Keynesian, one means the Keynesian Synthesis represented by the IS-LM-BP model of Hicks-Hansen-Mundell-Flemming. This paper will not deal with the Post-Keynesian model of Monetary Production Economy because it has never been implemented by developed economies.
} 
From this position, the monetary policy follows. Since money is not neutral either in the short-term or in the long run, monetary policy is part of economic policy and depends on the government. The central bank is under the control of political power and merely applies to the decided policy. The national dimension is privileged since it is the legitimate context of economy policy. To deal with international monetary relations in terms of the Bretton Woods agreement, i.e. a negotiated political agreement, fixed exchange rates are preferable to market mechanism. One thinks that a sufficient quantity of reserves of foreign currencies and a reasonable exchange rate are enough to keep the autonomy of monetary policy. Indeed, it is true that international financial exchanges are currently still low.

Monetary policy is part of the general framework of standard Keynesianism. The Philips curve is accepted; it is necessary to choose between inflation and unemployment. The IS-LM model is also widely accepted, even if some discussions appear about the shape of the LM curve and the distinction between money and financial assets. The Keynesian monetary policy follows four principles:

(1) Monetary policy is an element of a macroeconomic policy trying to fulfilfour objectives: the "magic square". Monetary policy, fiscal policy, and the management of the public debt must be coordinated to fulfil these objectives among which one gives priority to employment and production. A lot of emphasis is placed on the short-term. Internal and external objectives coexist.

(2) Monetary policy is judged to be ineffective and complementary to fiscalpolicy. If, in theory, credit conditions can have a strong influence, monetary policy should be avoided because of its potential negative consequences (instability of monetary policy instruments, financial instability, instability of the money demand via the speculative motive, liquidity trap, impacts on the balance of payments).

(3) The instrument is the money supply or the amount of liquidity and theobjective is the interest rate. One should rather stabilize the interest rate so as to not disturb investment. The impact of monetary policy goes through the interest rate channel and the credit channel by changing the liquidity position of financial institutions. But this impact is judged weak and slow to manifest itself: "One cannot push a string." (Porter Commission: 496)

(4) Official control of quantity is usually preferred to price control in the creditmarket (credit control) and the foreign exchange market. This is particularly true in case of difficult short periods. Moreover, selective policies are justified.

The Phillips curve completed awkwardly the IS-LM model, which originally did not integrate a mechanism of price determination. Also, fixed exchange rates are not really justified from a theoretical point of view. Finally, the "Horizontalist" tradition (demand determining completely the supply of money) cannot fully take into account banks' behaviors and the supply of money. Thus Keynesianism was not able to give relevant answers to the problems faced by developed countries in the early 1970s (inflation and floating exchange rates). 


\section{2) The Monetarist model of monetary policy}

The Monetarist model imposed itself progressively during the 1970s and signalled a renewal of a naturalist liberalism based on a modified quantitative theory of money. The general framework of natural laws leading a real economy to general market equilibrium is again accepted. However, following the dichotomous principle between monetary and real spheres, and contrary to growth or unemployment level (refusal of the Phillips curve), money does not depend on natural laws. Money is credit money and thus, as a construction of men, the market cannot manage it. Money is only neutral in the long-term and, therefore, it is the role of monetary authorities to neutralize money in the short-term. Inflation is only a monetary phenomenon.

Due to institutions like money, "Reason" is useful to preserve natural equilibrium. However, it is the "Reason" of an independent central bank that has the monopoly for the issue of high power money. Since a statesman has only short-term objectives, he disturbs the market equilibrium. The use of money for short-term objectives must be avoided absolutely, as it is unnecessary in the long run (natural equilibrium) and this policy would disturb the economy by causing inflation. The national dimension is given priority.

(1) Since money should not be regulated by the government and cannot bemanaged by the market, an independent central bank and technicians of money are entrusted with the aim of neutralizing money via a simple quantitative rule. The money supply should grow at a rate equal to the natural growth rate of production, which depends only on real factors.

(2) Monetary policy is effective and useful, but only for one long-term internalobjective: the regulation of inflation. Contrary to the discretionary policy of Keynesians, Monetarists want a strict monetary discipline via the respect of the rule.

(3) The instrument is the short-term interest rate and the objective is the stabilization of money supply as measured by aggregates (monetary base or monetary aggregates). The rate of interest can be changed rapidly and abruptly. The surprise effect may work. The demand for money and the velocity of money are assumed stable in the long run. This stability is reinforced if money supply is stabilized.

(4) One has to choose a flexible exchange rate system. The external stabilityof money (exchange rate) is the result of internal stability (no inflation).

In its willingness to systematically take the opposite view to Keynesianism, the Friedmanian Monetarism take many characteristics from it (a little like Marx with Ricardo): macroeconomic analysis gives priority to economic policy and so the national dimension, non-neutrality of money (in the short-term), institutional and historical approaches to money, consumption function linked to income, importance of the interest rate, etc.

If Monetarism is rapidly accepted, it will also be rapidly rejected at least in its initial form. One rapidly observes strong instability between monetary aggregates and inflation. These aggregates become impossible to define precisely. Financial innovation develops to avoid the rigorous monetary control. Moreover, flexible 
exchange rates do not lead to equilibrium prices, on the contrary. Crises become more and more frequent. Regions in constructions like Europe cannot accept this state of affairs. In the 1980s, numerous research articles and essays, mostly unsatisfying, were written. It was only at the beginning of the 1990s that a new monetary policy system appeared. More pragmatic than Monetarism, it keeps, however, the fundamental element of the latter.

\section{A "New Consensus" for monetary policy}

The New Consensus moved away from both Monetarism and standard Keynesianism. However, it is an orthodox consensus that takes a lot from New Keynesians. It can be summarized by the following four points:

- All expansionist fiscal policy leads to a higher inflation rate and to a higher long-term interest rate. (Romer, 2000)

- All restrictive monetary policy leads to a lower inflation rate without any effect on growth (otherwise positive) in the long run. (Romer, 2000)

- The real innovation is in not keeping an intermediary objective in terms of money supply (the link with prices is considered unstable like for Keynesians). One shifts the intermediary objective from a direct inflation target to a real rate of interest target (like heterodox Keynesians, which destabilize them sometimes). This interest rate rule is important (Taylor, 2000).

- In order to have a credible monetary policy, it must be implemented by an independent central bank.

This New Consensus (NC) will be more precisely characterized through the Canadian experience of the 1990s, which followed the in-depth transformation of the monetary and financial systems of the 1980s. The focus will be mainly on the progressive realization that uncertainty matters for monetary policy. This uncertainty pushed the disillusionment of the newly independent central bank.

\section{1) Uncertainty in monetary policy}

The central problem of the new monetary policy is the incorporation of uncertainty, notably on markets, and, so, of economic agent's expectations. The economy is more internationalized since financial markets have developed and funds for speculation are growing. Thus, a national monetary policy cannot be implemented like that of twenty or thirty years ago. Some of the consequences of this uncertainty are:

(1) An efficient monetary policy must influence long-term interest rate. Theserates are the only ones that are really significant for growth and the financing of growth (loans). Yet the link between short-term rates and long-term rates is not unequivocal. One can put forward six expectations that have an important influence on long-term interest rates: (1) the expectations concerning the long-term productivity of capital, economic growth and fiscal policy; (2) long-term expectation of inflation; (3) the current and expected level of the short-term interest rate 
("expectation theory") ${ }^{9}$; (4) risk premium as a function of the banks' liquidity preference; (5) the price of financial assets; (6) the current and future long-term foreign interest rates.

For example, if agents are confident ${ }^{10}$ that the central bank will decrease the short-term interest rate (no inflation expected, higher growth and so lower risk premium, low future short-term interest rate), the long-term rates will also go down. On the contrary, if their confidence is low (expectations of higher inflation rates, higher risk premium and stronger liquidity preference, high increase in short-term rate), then long-term interest rate will go up. Various scenarios show different evolutions, making the consequences of a monetary policy shock quite unclear.

(2) The demand for money is very unstable ${ }^{11}$ (Goodhart, 1993). Monetarism thus loses one of its fundamental hypotheses.

(3) The channels of transmission of monetary policy have become very complex and uncertain. It is very difficult for monetary policy to anticipate the most influential channel. The monetary channel is usually given priority. The impact of a variation of a short-term interest rate can go through the following: the cost of capital; expected inflation; the exchange rate; an income effect; and a substitution effect. However, a variation of interest rate also influences financial assets. The channel of asset prices can develop through a wealth effect, the Q-Tobin ratio or a real balance effect (Patinkin). Finally, these days, the balance-sheet channel (Bernanke) tries to integrate the development of financial market via the impact of a short-term interest rate variation on the balance-sheet structure of economic agents: the effect on net wealth, the value of collateral, financial charges, and the risk of liquidity and solvability crises for banks (Le Heron, 2002). The links between monetary policy and systemic financial crisis can be treated in the Minskian tradition (De Paula and Alves, 2000) or not (Mishkin, 1996). Of course, all these monetary policy channels lead to completely different conclusions.

(4) Today, liquidity crises are usually market liquidity crises rather than banking liquidity crises. There is a liquidity crisis in the market when nobody is ready to bid. Prices go down dramatically which withdraw all liquidity from financial assets: liquidity is defined as "the capacity to inverse a decision at any time and at the lower cost possible"12 (Bernstein, 1998). The rise of the amount of marketable assets in the balance sheet of banks makes the financial and banking system very

\footnotetext{
${ }^{9}$ In this expectation theory (Artus, 1997) the long-term interest rate depends on future short-term ratesof interest.

${ }^{10}$ One will see further why one talks about 'confidence' rather than 'credibility'.

${ }^{11}$ Keynes, Keynesians, and Post Keynesians have always put this instability forward. See Radcliffe Report.

12 The banking liquidity crisis corresponds to the intermediation risk. The monetary liabilities of banks can go down rapidly while they are not able to sell assets at the same pace. A lack of reserves (banking liquidities) leads banks to bankrupt. By being a lender-in-last-resort, the central bank can solve the crisis. On the contrary, in case of liquidity crisis in the market, the central bank or the Treasury must act a counterpart in last resort or a 'market-maker-in-last-resort'. They can solve this second type of crisis by
} 
sensitive to liquidity crises. These "new" crises are far more dangerous than those of the classical banking liquidity are. The impact of a monetary policy on asset prices (an increase of interest rate decrease automatically the value of financial assets) can itself generate a liquidity crisis on the market creating, via the fall in the value of assets, a solvability crisis of banks and insurance companies and a generalized financial crisis. The loss of confidence, along with a generalized preference for liquidity, explains the crisis of the productive sector (Japan).

\section{2) From the rule versus riscretion dilemma to the credibility versus confidence dilemma}

With the importance of expectations and the increasing role of financial markets at the global level, monetary policy has lost its certitudes. The new credo is credibility. But the relation between financial market and monetary policy is very complex. Its understanding goes through the use of "game theory". An important objective of monetary policy is to reduce uncertainty on the markets by trying to influence them, or by using the expectations and conventions of the financial markets.

By "uncertainty" one means a non-probabilistic, radical uncertainty, notably because it integrates the expectations of private agents, who base their decision on unstable conventions. Yet, these conventions are not only unstable but there are also unpredictable in terms of when they will change. This explains the willingness of the central bank to try to influence them with the transparency of its objectives and actions, and so the credibility of its monetary policy. For example, when the ECB increased its interest rates in 2000 while the Euro was in difficulty relative to the Dollar, the impact on the exchange rate was, contrary to theory, negative. Indeed, the convention of the market analyzed the weakness of the Euro as a consequence of the negative growth differential of Europe vis-à-vis the USA. However an increase in the interest rate on an economy with a low rate of growth - for which the market did not perceive any inflationary pressure contrary to the views of the ECB — led the market to penalize a policy that increased the problem instead of solving it.

Thus, in this paper, it is argued that it is necessary to distinguish between credibility and confidence. A central bank is "credible" when it "shows its determination to preserve the monetary system upon which it has engaged its credibility, in spite of deviations that it may consent to absorb economic shocks in the best possible conditions" (Aglietta, 1995: 112). In this way, a central bank is judged "credible" when economic agents think that the central bank will continue to follow the same rule, making its reaction function stable, despite the necessary adjustment to temporary economic conditions. Refers to "confidence" when there is a mutual understanding between the central bank and the economic agents, i.e., when the convention and the strategy of the central bank are in accordance with those of the other

buying at 'whatever price' the financial assets that have become illiquid. Then the risk of moral hazard is very high. 
participants (actors in financial markets, political power, and firms). Therefore, it is possible to have credibility without confidence and confidence may be limited. To over-simplify, one could say that the ECB implements a credibility policy (unfortunately in the opinion of some private agents), and the FED and BofC apply a confidence policy. Alan Greenspan defines the optimal level of inflation as the level at which agents stop to take inflation into account in their economic decisions. Statesman's "Reason" - either the government (Keynesians) or the central bank (Monetarist) - cannot impose itself easily on financial markets. To be effective, the New Consensus prefers confidence to the traditional Monetarist credibility. ${ }^{13}$

Following on from this, there is a real dilemma for the central bank in its relation with markets. This dilemma is the difficult choice to be made between credibility and confidence. The central bank has to convince the markets that its action is relevant so that it can use their power. In order to be credible, the central bank must show and respect a clear objective. Its strategy must be transparent, announced, and each modification of its instrument (short-term interest rate) must be explained, along with its analysis of the economic situation. This effort of communication aims at reducing not only uncertainty in relation to markets, but also the uncertainty that the markets have regarding inflation, interest rates, exchange rate, etc. The central bank has to reduce the risk of banking and financial crises by pretending to understand the markets, to accept their conventions, and be willing to help them if there is a problem (generalization of prudential rules, buyer in last resort, stabilization of financial asset prices). This is particularly true when financial markets experience a speculative bubble and when the economy is heavily indebted. This is also important for the influence of short-term interest rate of the monetary policy on long-term interest rate.

The problem is that in order to have an effective and credible monetary policy, central banks cannot always follow the expectations of the markets because this generates a high moral hazard. The history of monetary and financial crises of the last 30 years shows without doubt that a credit divisor system is at work. ${ }^{14}$ The central bank only implements tight liquidity policy when it is sure it will not endanger the banking and financial system: i.e., when its "aggressiveness" can be supported by the system. The central bank notably avoids endangering the most important banks ("too big to fail" principle ${ }^{15}$ ). Several authors have stated that the rapid decrease in the Fed rates in 2001 was led by the desire not to "burst the bubble". Indeed, a policy that tries to hold on to the basics is hopeless except when

\footnotetext{
13 This is all the more the case for the latter that credibility is founded on the respect of an underlying model, which is considered as relying on natural laws: the Walrasian general equilibrium and the NAIRU. Thus a Monetarist central bank thinks that it knows the "true real model".

${ }^{14}$ The credit divisor system was developed in 1952 and 1962 by Jacques Le Bourva (Baslé and Lavoie, 1996). The Mexican and Japanese crises as well as the Savings and Loans bailout in the US and the Crédit Lyonnais bailout in France, are good example of the existence of this system.

${ }^{15}$ It is indeed usually difficult for a central bank to make a difference between liquidity crisis (that central bank has to manage) and a solvability crisis (that private bank should manage by itself).
} 
the convention changes, i.e., when it is too late. This is because if there is a disagreement between the central bank and the markets, the latter always impose their view. The recent example of the Euro and the NASDAQ is a good illustration of this state of affairs.

Thus independent central banks are like a statue with feet of clay. They cannot impose their view via their own rule; they have instead to use the expectations of the market as leverage to amplify the effect of their actions. In this way, the expectations of the markets must be similar to that of central banks. It is crucial to avoid bad interpretations, which leads to systematic pedagogical efforts and tactics coming from game theory. There are far more complex than the simplistic insurance problem and the surprise effect of the quantitative Monetarist policy.

"The Bank tries to work with markets, rather than against them, to avoid surprising them with unexpected actions. Greater transparency facilitates the policy-transmission process by conditioning market expectations, and helps avoid unnecessary confusion about the reasons for our actions". (Thiessen, 2000-2: 79)

"We no longer regard surprise as an important element in monetary policy actions. We prefer to see private agents anticipate, rather than respond to, monetary policy actions." (Thiessen, 2000-2: 79)

Some authors go further. Norman Cameron notes that:

"The central bank should place more emphasis on private sector forecasts of inflation when deciding how to respond to a shock. If private sectors forecasters suggest that inflation is expected to rise above the target, the central bank should tighten monetary conditions, and when private sector forecasts predict that inflation will be below the target, monetary conditions should be relaxed." (Cameron, 1997: 76)

The objective is not to affect the real conditions of the economy but rather to directly influence the expectations of private agents, which are judged selffulfilling. The central bank, by giving a sign that it has understood the market, anticipates a change of expectations and so of the behaviour of economic agents. The central bank then creates the condition of a high moral hazard. If it follows too closely the main opinion in the market (choice of confidence), the expectations of the market might determinate monetary policy and thus put into question its credibility. Indeed, if the central bank divulges its reasoning in the name of transparency, the forecasters of the private sector will be able to manipulate their expectations and make threats, in order to get the monetary policy that they want. For example, they will insist on the necessity to decrease interest rate and to inject liquidities in front of the risk of crash or of market liquidity crisis. Currently, there is a strong pressure on central banks to become not only lenders-in-lastresort, but also "counterparts-in-last-resort". To put it another way, there is pres- 
sure to make them ensure the market liquidity when there are no institutional buyers and when financial asset prices collapse. By not following the view of markets in the name of credibility and moral hazard (refusal of confidence), the central bank take the risk of strong financial instability and non-optimal economic situation (slow growth).

Therefore, we can see that the words Transparency, Communication, and Credibility, arise from the central banks' willingness to "manipulate" the expectations of the private sector. In this game of cat and mouse, the problem is knowing if this new consensus will be robust enough to fulfil the objectives. Far from seeing an exogenous monetary policy fixed by an independent central bank, one observes instead an endogenous monetary policy trying to maintain appearances. This is all the more the case if the country is dominated monetarily. If the final objective is still a low level of inflation, the intermediary objectives can rapidly change to adapt to the most influential expectations in the markets. These intermediary objectives can be the expected price level (CPI*), the price of financial assets, or the exchange rate. Consequently, the management of the interest rate, which is the instrument of these different intermediary objectives, becomes very complex.

\section{3) The characteristics of the New Consensus}

While the new monetary policy owes a lot to the microeconomic studies of New Keynesians (asymmetry of information, moral hazard, adverse selection, etc.), it has taken very little from New Classical and ultra liberal views. We are far from a renewal of Hayekian liberalism for which reason (even that of an independent central bank) and instincts are the worst enemies of liberal order. The theories concluding with the end of a central bank and the imposition of market law to money (free banking, Hayek) are not established. Moreover, the rational expectations, which have heavily influenced monetary theory for the previous twenty years, have not aided this pragmatic monetary policy. The switch from a personal element to an automatic monetary rule, like that proposed by Taylor in 1993, has actually not been implemented by any central banks, even if this rule influences the determination of the real interest rate as an intermediary objective. The Bank of Canada states, for example, that its Monetary Conditions Index should be used pragmatically and should take into account the state of opinion in the markets.

"There are also times when markets become particularly nervous and volatile because of economic shocks or concerns about policies, and central bank actions have to be directed to coping with disorderliness in markets... In such circumstances, the Bank's immediate task was to calm markets by helping them to find new trading ranges with which they were comfortable.” (Thiessen, 1995: 9) 
Three elements characterize the foundational institutional structures of the new consensus:

Firstly, the independence of the central bank is greatly emphasized and usually justified by the anchorage of monetary policy in the long run. From the operational point of view, this independence is absolute. A long mandate for governors shows this search for the long-term: 7 years in Canada, 6 years for the ECB. Thus, a government, democratically elected on a Keynesian agenda, would not have the possibility of implementing it today. Indeed, the autonomy of the monetary policy is a tool used exclusively by the central bank, and not by governments. This institutional change is not neutral because there is no symmetry. A government, democratically elected on a Monetarist agenda, could implement the change with or without an independent central bank (like in the UK in the 1980s). Thus "Reason" is transferred from politicians to central bankers, that is to say, from short-term to the medium and long-term. The statesman, who is suspected of employing Keynesian theory, is "unreasonable" in term of monetary policy:

"Neither the ECB, nor any member of it executive organ, can solicit or accept instruction from institutions of the European Union, from governments of member States or from any other organism" (Statute of the ECB)

Secondly, the independence implies a greater responsibility. In order to maintain at least a flavour of democracy within central banks, their responsibility must be increased. Therefore, a committee, partly nominated by governments, increasingly decides the monetary policy (only 6 nominated at the ECB against 12 central bankers). However, the work is done upstream of the ECB by the research services of central banks. It would require an individual with a very strong personality to go against the propositions sustained by the governor. The democratic legitimacy of these monetary councils is very weak, even if central banks must usually give an account of their policy to the parliament.

Thirdly, its independence and its responsibility force the central bank to communicate more broadly. The bank must also be transparent about its objectives (explicit target of inflation), its methods to reach these objectives and its view on the economic situation. Fixed dates of appointment, detailed regular reports, publication of the discussion of the monetary policy council, clear procedures of intervention, are all part of this willingness to be transparent. However, this paper has shown that this diffusion of information must be limited to not going against the policy of the central bank. Playing with the market is a dangerous game. That is why, today, the development of prudential regulation seems to be very fruitful. This is partly an admission of failure as, not being able to resolve the new crises, the central bankers try to avoid them early on. However, perhaps no prudential rules will ever be sufficient to avoid these crises. 
Table 1: Summing up the Problematic of Each Monetary System

\begin{tabular}{l|l|l|l}
\hline \multicolumn{1}{c|}{ Monetary system } & Keynesian Consensus & Monetarist Consensus & "New Consensus" \\
\hline Type of liberalism & $\begin{array}{l}\text { Social democracy } \\
\text { Importance of "Reason" } \\
\text { and of normative choices } \\
\text { of man. Discretionary } \\
\text { action of the State }\end{array}$ & $\begin{array}{l}\text { Naturalist liberalism, } \\
\text { general equilibrium of } \\
\text { market, rejection of } \\
\text { the reason of statesman } \\
\text { except for money }\end{array}$ & $\begin{array}{l}\text { Liberalism, partial } \\
\text { market equilibrium, } \\
\text { asymmetry of } \\
\text { information and of } \\
\text { power of agents, the } \\
\text { State interacts with } \\
\text { markets }\end{array}$ \\
\hline $\begin{array}{l}\text { Approach, foundations } \\
\text { Neutrality of money }\end{array}$ & $\begin{array}{l}\text { Mocroeconomics } \\
\text { No }\end{array}$ & $\begin{array}{l}\text { Mo in the short-term } \\
\text { Yes in the long-term }\end{array}$ & $\begin{array}{l}\text { No, but it depends on } \\
\text { expectations and } \\
\text { information }\end{array}$ \\
\hline $\begin{array}{l}\text { Monetary and financial } \\
\text { the period } \\
\text { specialization }\end{array}$ & $\begin{array}{l}\text { National. Strong } \\
\text { intermediation, economy } \\
\text { of indebtedness, banking } \\
\text { specialization }\end{array}$ & $\begin{array}{l}\text { Deregulation, } \\
\text { disintermediation, } \\
\text { capital market } \\
\text { economy }\end{array}$ & $\begin{array}{l}\text { Globalization } \\
\text { of financial flows } \\
\text { and financial } \\
\text { markets }\end{array}$ \\
\hline
\end{tabular}

Even if the New Consensus borrows more from Monetarism than Keynesianism, it is deeply different to it, particularly in its implementation. Neither is this consensus a synthesis of two predecessors. One can sum up in three tables the differences between each system of monetary regulation, since a monetary policy system is built out of the three levels of an Economic Policy System. Firstly, there is the problematic, which expresses the philosophical and moral options regarding the conception of man and society. It thus considers the finality and the nature of economics, by clarifying the questions judged to be the most relevant.

Secondly, there is the analysis, which develops, via hypotheses, a system that can answer questions that are asked. This analysis explains the functioning of the economy by specifying the given facts, the variables, and the functional and causal relations.

Table 2: Summing up the Analysis

\begin{tabular}{|c|c|c|c|}
\hline Monetary system & Keynesian Consensus & Monetarist Consensus & "New Consensus" \\
\hline Foundational theory & $\begin{array}{l}\text { IS-LM-BP model, } \\
\text { endogenous demand of } \\
\text { money, exogenous supply } \\
\text { of money }\end{array}$ & $\begin{array}{l}\text { Quantitative equation, } \\
\text { exogenous demand } \\
\text { and supply of money }\end{array}$ & $\begin{array}{l}\text { Game theory and } \\
\text { theories of } \\
\text { expectations }\end{array}$ \\
\hline Type of expectations & Extrapolative & Adaptive and others & Self-fulfilling \\
\hline Financial markets & Not important & Neutral & Very important \\
\hline Financing of the State & Yes, budgetarism & $\begin{array}{l}\text { Without any foundations } \\
\text { because of the neutrali- } \\
\text { zation of public spending }\end{array}$ & $\begin{array}{l}\text { Forbidden, but fiscal } \\
\text { policy is possible in } \\
\text { certain limits }\end{array}$ \\
\hline
\end{tabular}




\begin{tabular}{l|l|l|l}
\hline Origin of inflation & $\begin{array}{l}\text { Excess of demand and } \\
\text { costs of production, } \\
\text { Phillips curve }\end{array}$ & Excess of money & $\begin{array}{l}\text { Excess of demand } \\
\text { and expectations }\end{array}$ \\
\hline Exchange rate system & Fixed & Floating & Flexible \\
\hline Demand for money & Unstable & Stable & Unstable \\
\hline Central bank & $\begin{array}{l}\text { Depends on the } \\
\text { Government }\end{array}$ & Independent & Independent \\
\hline
\end{tabular}

Thirdly, there is the analytical superstructure or economy policy that develops some means of action. It aims at making the world closer to how it should be.

Table 3: Summing up the Monetary Policy

\begin{tabular}{|c|c|c|c|}
\hline $\begin{array}{l}\text { Monetary } \\
\text { system }\end{array}$ & $\begin{array}{l}\text { Keynesian } \\
\text { Consensus }\end{array}$ & $\begin{array}{l}\text { Monetarist } \\
\text { Consensus }\end{array}$ & $\begin{array}{l}\text { "New } \\
\text { Consensus" }\end{array}$ \\
\hline Determination & Government & Central bank & Central bank \\
\hline Scale of political action & National & National & $\begin{array}{l}\text { National, regional } \\
\text { and global }\end{array}$ \\
\hline $\begin{array}{l}\text { Effectiveness } \\
\text { of monetary policy }\end{array}$ & Rather low & Strong on inflation & Strong if credible \\
\hline Final objective & Magic square & Price stability & Price stability \\
\hline $\begin{array}{l}\text { Intermediary } \\
\text { targets }\end{array}$ & $\begin{array}{l}\text { Interest rate and } \\
\text { exchange rate }\end{array}$ & $\begin{array}{l}\text { Money supply or } \\
\text { monetary base }\end{array}$ & $\begin{array}{l}\text { Inflation-control target } \\
\text { so, expected inflation, } \\
\text { financial asset prices, } \\
\text { and exchange rate }\end{array}$ \\
\hline Instrument & $\begin{array}{l}\text { Adaptation of the } \\
\text { supply to the money } \\
\text { demand }\end{array}$ & $\begin{array}{l}\text { Short-term interest } \\
\text { rate }\end{array}$ & $\begin{array}{l}\text { Real interest rate, } \\
\text { transparent information }\end{array}$ \\
\hline $\begin{array}{l}\text { Time-scale of monetary } \\
\text { policy }\end{array}$ & Short-term & Long run & Medium and long run \\
\hline $\begin{array}{l}\text { Transmission } \\
\text { channel of } \\
\text { monetary policy }\end{array}$ & $\begin{array}{l}\text { Interest rate } r \\
\text { loan (financing of } \\
\text { the economy), } \\
\text { exchange rate } e\end{array}$ & $\begin{array}{l}\text { Quantitative theory, } \\
\text { wealth effect }\end{array}$ & $\begin{array}{l}\text { Multiple and complex } \\
\text { (r,e, loans, expectations, } \\
\text { announcement effect, } \\
\text { financial asset prices, } \\
\text { balance sheet) }\end{array}$ \\
\hline Strategy & $\begin{array}{l}\text { Discretionary and } \\
\text { contra-cyclical }\end{array}$ & $\begin{array}{l}\text { Rule, strict monetary } \\
\text { discipline and surprise } \\
\text { effect }\end{array}$ & $\begin{array}{l}\text { Credibility and/or } \\
\text { confidence, } \\
\text { stabilization of } \\
\text { expectations, } \\
\text { transparency and } \\
\text { permanency } \\
\end{array}$ \\
\hline
\end{tabular}

Therefore, it can be seen that the New Consensus on monetary policy has been heavily influenced by the fundamental role played by expectations and credibility and more generally, by the intellectual context of New Keynesian economics. A credible central bank fulfils its objectives more easily and a credible central bank "must" be independent. The convergence toward low levels of inflation in industri- 
alized countries, as well as the decrease in long-term expectations of inflation, seems to justify this new monetary policy.

However, in addition to the deflationist bias - on which this paper will give no opinion - one can see that this consensus rests on weak political and economical foundations. The independence of central banks creates a lack of democracy. Indeed, in addition to the autonomy of the monetary policy, central banks meddle increasingly in fiscal policy (which they try to neutralize) and even in income policy (wage policy). The ECB is a good example of this. Thus, economic policy is determined increasingly by central bankers who leave less and less space to democratically elected governments. For numerous countries (Brazil, Argentina), the role and action of the IMF (particularly with the second Washington consensus $^{16}$ ) accentuated this evolution.

Nonetheless, monetary policy seems more and more endogenous. Rather than "credibility", we should refer to "confidence" and "shared strategy". There is ambiguity concerning the real control of monetary power. The importance given to the increasingly powerful psychology of the markets could rapidly upset the fragile equilibrium of the banking and the financial systems in our countries. Here once again, now more than ever, there is uncertainty.

\section{REFERENCES}

AGLIETTA Michel (1995) Macroéconomie financière. Repères, La Découverte.

AGLIETTA Michel et alii (1995) “Actifs patrimoniaux et dynamiques économiques", Cahiers Économique et Monétaire de la Banque de France, $\mathrm{n}^{\circ} 44$.

AGLIETTA Michel (2000) "Systèmes financiers et régimes de croissance", Conference of the CDC Research Institute, June.

AKHTAR M. (1994) "Monetary policy effects on long-term interest rate: a critical survey of the empirical literature", Research paper of the FED of New York, n 9407.

ARTUS Patrick (1997) "La réaction des taux d'intérêt et de la structure des taux d'intérêt aux chocs inflationniste et à la crédibilité”. Working paper of the CDC, nº 1997-02/FI.

BASLÉ M. and LAVOIE Marc (1996) "La pensée monétaire de Jacques Le Bourva, analyse et historique”, Revue d'Économie Politique, $\mathrm{n}^{\circ} 1$.

Bank of Canadá Annual reports, notes, introduction to the monetary policy, refer to the Web site.

Bank of Canadá (2001) "Reconduction de la cible de maîtrise de l'inflation”, note, May.

Bank of France Annual reports, notes, introduction to the monetary policy, refer to the Web site.

BERNSTEIN Peter L. (1998) "Stock market risk in a Post-Keynesian world", Journal of Post-Keynesian Economics, Fall, 21 (1).

BRESSER-PEREIRA L.C. and NAKANO Y. (2002) “Economic Growth with Foreign Saving?” unpublished.

CAMERON Norman (1997) in Tiff Mackleen "Summary of the conference on Price Stability, Inflation Targets and Monetary Policy”. Bank of Canada, May, www.bankofcanada.ca.

CLINTON Kevin (1997) "Implementation of Monetary Policy in a regime with zero reserve Requirements”, Working paper n ${ }^{\circ}$ 97-8, Bank of Canada.

DODGE David (2001) "La Banque du Canada et la politique monétaire: les grandes orientations",

${ }^{16}$ For an analysis of the second Washington consensus, see (Bresser-Pereira and Nakano, 2002). 
Remarks by David Dodge, Governor of the Bank of Canada, to the Toronto Chamber of Commerce, February.

DODGE David (2002) "Promoting Canada's Economic and Financial Welfare”, Remarks by David Dodge, Governor of the Bank of Canada to the Calgary Chamber of Commerce, November.

DRUMETZ Françoise (2000) "Mondialisation et intégration régionale: les conséquences pour la conduite de la politique monétaire", Bulletin de la Banque de France, $\mathrm{n}^{\circ} 73$, January.

DRUMETZ Françoise (1997) "Règle de Taylor: présentation, application, limites", Bulletin de la Banque de France, $\mathrm{n}^{\circ} 745$, September.

European Central Bank Annual reports, notes, presentation of the monetary policy, refer to the Web site.

FLOUZAT Denise (1999) "Le concept de banque centrale", Bulletin de la Banque de France, $\mathrm{n}^{\circ}$ 70, October.

FREEDMAN Charles (1995) "Le rôle des conditions monétaires et de l'indice des conditions monétaires dans la conduite de la politique", Remarks by the Deputy Governor of the Bank of Canada at the Toronto University conference L'évolution internationale et les perspectives économiques pour le Canada, June.

GOODHART Charles (1993) "La politique monétaire dans les années 1990: objectifs et moyens d'action", Cahiers Économique et Monétaire de la Banque de France, $\mathrm{n}^{\circ} 41$.

GREUET Jean-Yves (2000) "Indépendance et responsabilité: évolution du métier de banquier central”, Bulletin de la Banque de France, ${ }^{\circ}$ 82, October.

JAILLET and SICSIC Pierre (1998) "Prix d'actifs, relations avec les facteurs de la demande et le crédit: quelques implications pour la politique monétaire", Bulletin de la Banque de France, n' ${ }^{\circ} 53$, May. LAIDLER David (2001) "Foreword", The Thiessen Lectures, edited by the Bank of Canada.

LALONDE R., PAGE J. and ST. AMAND P. (1998) "Une nouvelle méthode d'estimation de l'écart de production et son application aux Etats-Unis, au Canada et à l'Allemagne”, Working paper $n^{\circ}$ 982, Bank of Canada.

LAVOIE Marc (2002) "A post-Keynesian alternative to the New consensus on monetary policy", CEMFADEK international conference, Dijon, France, November.

LE HERON Edwin (2002) "La préférence pour la liquidité des banques: une analyse post-keynésienne du comportement bancaire”, Les Cahiers Lillois d'Économie et de Sociologie, nº 38.

MACKLEM Tiff (1997) "Résumé du colloque sur la stabilité des prix, les cibles en matière d'inflation et la politique monétaire", and papers of the conference organized by the Bank of Canada: Price Stability, Inflation Targets and Monetary Policy, May.

MISHKIN Frederic (1996) "Les canaux de transmission monétaire: leçons pour la politique monétaire" Bulletin de la Banque de France, $\mathrm{n}^{\circ}$ 27, March.

PATAT Jean-Pierre (2000) "La stabilité financière, nouvelle urgence pour les banques centrales", Bulletin de la Banque de France, no 84, December.

DE PAULA Luiz and ALVES A. J. (2000) "Banking behavior and margins of safety in a minskyan business cycle”, CEMF-ADEK international conference, Dijon, France, November.

PAULIN Graydon (2000) "La transformation du visage des banques centrales durant les années 1990", Bank of Canada Review, p. 3-15, Summer.

PEYTRIGNET Michel (2000) "Politique monétaire suisse en changes flexibles: la pratique des objectifs monétaires”, Working paper, Bank of Canada, with the reply by Chantal Dupasquier, Daniel Racette and Denise Côté, p. 223-265.

Radcliffe Report (1959) Committee on the Working of the Monetary System (named Radcliffe Report), Report, London, Her Majesty's Stationery Office, August.

RAYMOND, Aron (1969) “Qu'est ce que le libéralisme?”, speech on November 18, 1969. Commentaire (Review), Winter 1998-1999, $\mathrm{n}^{\circ} 84$.

ROMER D. (2000) "Keynesian macroeconomics without the LM curve", Journal of Economic Perspectives, 14 (2), Spring.

ROSENWALD Fabienne (1995) "L'influence de la sphère financière sur la sphère réelle: les canaux du crédit”, Bulletin de la Banque de France, First Quarter. 
SECCARECCIA Mario (2001) "Is the Canadian dollar destined to disappear? The case against dollarization", International Conference on "Monetary and Financial Integration: Lessons from Europe for the Americas. The Debate over Dollarization”, Kalamazoo College, Michigan, U.S.A., May.

TAYLOR J. B. (2000) "Teaching modern macroeconomics at the principles level“, American Economic Review, 90 (2), May.

THIESSEN Gordon (1995) "Uncertainty and the Transmission of Monetary Policy in Canada", The Hermes-Glendon Lecture, delivered at York University, Glendon College, Toronto, March.

THIESSEN Gordon (1998) “The Canadian Experience with Targets for Inflation Control”, The Gibson Lecture, delivered by Governor Gordon Thiessen at Queen's University, Kingston, October.

THIESSEN Gordon (1999-1) “L'avènement de l'Euro: son incidence économique et les leçons à tirer de cette expérience", Remarks to the Canadian Club of Ottawa, January.

THIESSEN Gordon (1999-2) "Then and Now: The Change in Views on the Role of Monetary Policy since the Porter Commission “, The Tony Hampson Memorial Lecture by Gordon G. Thiessen, Governor of the Bank of Canada, C.D. Howe Institute, Toronto, Ontario, March.

THIESSEN Gordon (2000-1) "La conduite de la politique monétaire dans un pays voisin d'une grande puissance économique”, Speech to the Canadian Society of New York, Bank of Canada Governor Gordon Thiessen, March.

THIESSEN Gordon (2000-2) "Can a Bank Change? The Evolution of Monetary Policy at the Bank of Canada 1935-2000", Lecture by Gordon Thiessen, Governor of the Bank of Canada to the Faculty of Social Science University of Western Ontario, October.

THIESSEN Gordon (2000-3) "Pourquoi un régime de changes flottants est-il le meilleur choix pour le Canada?", Remarks by Gordon Thiessen, Governor of the Bank of Canada to the Chambre de commerce du Montréal métropolitain, December.

WEB <www.banqueducanada.ca>, <www.banque-France.fr >, <www.ecb.int> 